\title{
Caring for cancer patients in the Covid pandemic: choosing between the devil and deep sea
}

\author{
Mainak Chakraborty and Manoj Pandey ${ }^{*}$ (D)
}

\begin{abstract}
Background: Healthcare is an essential service at any time more so in the crisis like Covid. With increase in number of cases and mortality from Covid, the primary focus is shifted to the management of the Covid crisis and other health emergencies thus affecting normal health services and routine treatment of other diseases like cancer.

Methods: This article reviews the published literature and guidelines on Covid and cancer and discusses them to optimize the care of cancer patients during Covid pandemic to improve treatment outcomes.

Results: The results of the review of published literature show a twofold increase in probability of getting CoV2 infection by the cancer patients and a four-fold increase in chance of death. On the other hand, if left untreated a $20 \%$ increase in cancer death is expected. Data further show that none of the medicines like remdesivir, hydroxy chloroquin, dexamethasone, or azithromycin improves survival and response to Covid in cancer patients. Surgical results too show similar outcome before and after the pandemic though most of these report on highly selected patients populations.

Conclusions: The Covid 2019 pandemic places cancer patients in a very difficult situation wherein if they seek treatment, they are exposing themselves to a risk of developing CoV2 infection and if they do not, the probability of dying without treatment increases. Hence, for them it is a choice between the devil and deep sea, and it is for the healthcare providers to triage patients and treat who cannot wait even though the data from the carefully selected cohort of patients show no increase in mortality or morbidity from treatment during Covid.
\end{abstract}

Keywords: Covid, Cancer, Cov2, Coronavirus, Treatment, Chemotherapy, Surgery

\section{Introduction}

With the onset of Covid-19 pandemic, the situation for cancer patients has become a nightmare. Most of the patients who were on treatment in March had to miss out their further treatment due to lockdown and closure of hospitals and all modes of transport, both public and private. Those who developed cancer during lockdown too could not reach doctors for the same reason. Surgeries were postponed, radiotherapy was postponed, and there

\footnotetext{
* Correspondence: manojpandey66@gmail.com

Department of Surgical Oncology, Institute of Medical Sciences, Banaras Hindu University, Varanasi 221005, India
}

was uncertainty as far as chemotherapy and immunotherapy were concerned. Every society and organization came up with their own guidelines; however, none of these addressed the logistic problems that patients faced reaching the treatment centers. This lead to an increased pool of untreated patients; an analysis from England estimates additional 6270 deaths from cancer over next 12 months that is $20 \%$ increase proposed due to Covid pandemic [1].

Those who were willing to travel and take the risk of getting infected with Covid-19, too, faced challenges due to travel restrictions, though the Indian government issued special passes to allow travel for cancer treatment;

(c) The Author(s). 2020 Open Access This article is licensed under a Creative Commons Attribution 4.0 International License, which permits use, sharing, adaptation, distribution and reproduction in any medium or format, as long as you give appropriate credit to the original author(s) and the source, provide a link to the Creative Commons licence, and indicate if changes were made. The images or other third party material in this article are included in the article's Creative Commons licence, unless indicated otherwise in a credit line to the material. If material is not included in the article's Creative Commons licence and your intended use is not permitted by statutory regulation or exceeds the permitted use, you will need to obtain permission directly from the copyright holder. To view a copy of this licence, visit http://creativecommons.org/licenses/by/4.0/ The Creative Commons Public Domain Dedication waiver (http://creativecommons.org/publicdomain/zero/1.0/) applies to the data made available in this article, unless otherwise stated in a credit line to the data. 
however, the rider was that he or she has to travel with his own private transport and not more than two people were allowed in a four wheeler. This meant that apart from the driver, only the patient could travel without any caregiver, if the patient does not own the car and caregiver does not know how to drive. These passes were issued district or state wise as there was a ban on inter-district and interstate travel, so the patients coming to bigger institutes like ours faced special problems wherein despite having a travel pass, some of them had to pay fines. Most of our patients come from neighboring states of Bihar and Madhya Pradesh and even from West Bengal and Nepal.

Apart from that, at the beginning of the pandemic things were not clear and there was no data on the incidence and mortality from Covid-19 in cancer patients; further, though there were several guidelines [2-8], they were not based on evidence as the evidence did not exist at that time and it was not clear as to what treatment modalities are safe, giving rise to uncertainties in the mind of patients and health care workers. The testing facilities were limited, the availability of PPE was limited and these were prioritized for suspected cases and contacts, while other diseases were kept on hold or received low priority. This article reviews the current literature on various aspects of Covid and cancer.

\section{Methods}

A review of literature was carried out using the pubmed for the articles published using the string "covid"[All Fields] AND $\left(\left(\left(()\left(\left(()^{\prime}\right.\right.\right.\right.\right.$ cancer s"[All Fields] OR "cancerated"[All Fields]) OR "canceration" [All Fields]) OR "cancerization" [All Fields]) OR "cancerized"[All Fields]) OR "cancerous"[All Fields]) OR "neoplasms"[MeSH Terms]) OR "neoplasms"[All Fields]) OR "cancer"[All Fields]) OR "cancers"[All Fields]). Following filters were applied Clinical Study, Clinical Trial, Comparative Study, Controlled Clinical Trial, Meta-Analysis, Observational Study, Pragmatic Clinical Trial, Randomized Controlled Trial.

The articles that discussed the incidence, prevalence, mortality, treatment of cancer during Covid, or morbidity of treatment were included in the review. As the obtained data was very heterogeneous, no attempt at pooling or meta-analysis was done.

\section{Results}

A total of 65 articles were extracted, the abstract of all the articles was read and after excluding reviews, 38 articles were included in this review including one metaanalysis. As for the prevalence, the initial data from a multicentric study comparing cancer with non-cancer patients infected with Covid found higher incidence of severe outcome in cancer compared to normal; the outcome was worse in lung cancer and metastatic disease
[9]. A study evaluating fatality in 44,672 patients with Covid found a 2.9 times risk of death in cancer patients contracting Covid [10].

This fear and uncertainty had affected the quality of life and metal health of cancer patients, caregivers, and health care workers. There were no socializing, no outlets, no markets or movies or dining out, even the places of worships were closed. An Italian survey of young cancer patients showed that they feel more vulnerable to contract cancer, and risk of higher complications [11]. A higher burnout has been reported in healthcare workers working in Covid hospitals [12].

Over a period of time, things have started clearing up and preliminary data on incidence, severity, and complications of Covid-19 is now available. A retrospective analysis of 1590 patients across mainland China reported $16 \%$ incidence of severe cases [13]. Of these, 399 (25.1\%) had at least one co-morbidity with hypertension (16.9\%) being most prevalent followed by diabetes (8.2\%). In this study, the cancer was seen only in $10(0.9 \%)$ patients of whom 7 had severe illness. Another study from China on 1509 patients with Covid had 18 patients with cancer [14]. They too found higher severity in cancer patients; however, the number of cancer patients in this study too was very small. Similarly, the study of Chen et al. [15] had 10 patients in total of 1099 Covid-19 patients and only three of these had a severe disease. Similar results have been reported by others $[16,17]$.

A pooled meta-analysis of 11 studies reporting on Covid prevalence in cancer patients found a pooled prevalence of $2.0 \%$; prevalence was higher at $3 \%$ in smaller series reporting on less than 100 patients [18]. Between March and June 2020, over 5400 patients were seen at our center, of which 237 undergoing surgery or the interventions were tested for Covid; of these, 9 patients were found to be positive (3.7\%). The prevalence of cancer is high among Covid-19 patients in Europe; however, these do not seem to convert into higher mortality of cancer patients. A study from UK reporting on 226 deaths did not find increased mortality in cancer except in patients receiving chemotherapy [19]. However, a meta-analysis involving 46,499 patients that included 1776 cancer patients showed a significant increase in hazard of death in cancer patients infected with Covid19 (HR 2.03) [20]. The study also showed increased admission to ICU (HR 1.56); however, when patients above the age of 65 were considered, no difference in death rate was observed [20]. This increase in cancer mortality in Covid-19 has been attributed to advance age, additional co-morbidities, diagnosis of lung cancer, use of chemotherapy etc. [19, 21-25].

Recent data from the USA, Canada, and Spain from the COVID-19 and Cancer Consortium (CCC19) database reported on 928 patients with cancer; of these, 121 
(13\%) patients had died [26]. Advance age, smoking, male gender, more than one co-morbidity, and ECOG more than 2 were found to be associated with increased mortality. These results and those detailed above clearly show that prevalence of Covid in cancer is higher and mortality in these patients too is higher, especially in patients with additional co-morbidities and active disease, and one needs to exercise full precaution while taking treatment decisions.

\section{Discussion}

\section{Precautions taken at our center to prevent spread in cancer patients}

As cancer patients are at a higher risk of contracting Covid-19 than the general population, special precautions are taken when patients are seen in the outpatient clinic (OPD) and surgery. No patient or the caregiver is allowed to enter the OPD without a face mask, all patients are screened for body temperature, and those found to have fever are immediately sent to Covid OPD. This is followed by filling up of a symptom checklist and questionnairebased screening for all patients. Those with Covid symptoms are referred for RT-PCR testing before being allowed to see doctor and get the treatment. This is similar to all others coming to the hospital for treatment as there are no separate guidelines for cancer, apart from that strict hand hygiene is followed and PPE has to be worn by health care workers. Those planning to undergo procedures and surgery are screened for Covid-19 using RTPCR testing. They are kept in the holding area and after being reported are shifted to wards. Any patient found positive is treated as per guidelines.

\section{Planned surgery}

Elective surgeries for cancer patients are avoided if possible, this is usually a collective decision taken by the oncologist in consultation with the patient. If it is decided to do a surgery, a special Covid-19 consent is taken. All emergency surgeries are performed with proper written Covid consent and after Covid testing for even asymptomatic patients. Other than emergencies, patients who cannot wait for 4 weeks for surgery as the disease may progress and become inoperable are considered for surgery. Other than that, patients who were started on neoadjuvant therapy before the onset of Covid and have now completed neoadjuvant therapy are also candidates for surgery, as the opportunity of window period should not be lost. Any patient where the multidisciplinary team think can wait for 4 weeks is postponed. Patients undergoing surgery are reported to be at higher risk than those treated by radiation [9].

\section{Planned radiotherapy}

In the beginning, all patients were postponed after discussion with patients or caregivers; however, as it is not possible to postpone radiation forever, selected patients are now being taken up for radiation. Patients are informed that whatever little evidence that is available suggest higher chances of Covid infection in this subset of patients. Recent guidelines have suggested omitting radiation for patients older than 65 years, using FAST and FAST forward, omitting boost, and hypofractionation $[13,14]$. Recent articles also suggest modification of the delivery technique to reduce treatment time $[27,28]$.

\section{Immunosuppressive therapy}

The current evidence does not support changing or withholding chemotherapy, targeted therapy, and immunotherapy in cancer patients. Some of the studies suggested stopping of immunotherapy for patients who have a complete response or prolonged response of more than 2 years [29]. A report on immune check point inhibitors suggested that as there is not much immune compromise and minimal hematological toxicities, they can be used with caution as patients are not devoid of its benefits [30,31]. At our center, we have continued with chemotherapy and immunotherapy and have not found any increase in Covid-19 infection or mortality in this sub group.

\section{Stem cell transplantation}

Current guidelines recommend delaying the planned allogenic stem cell transplant [32, 33]. This is a unique situation where the donor and recipient both are at risk and a careful decision making keeping all factors into account be made. No stem cell transplants took place at our center during this period.

\section{Coronavirus therapy in cancer}

There is no evidence of benefit of using various therapies to treat Covid-19 in cancer patients. Remdesivir has been approved by the FDA for treatment of Covid cases under emergency use authorization. The CCC19 study failed to show any benefit of azithromycin, hydroxy chloroquine, alone or in combination; in fact, use of a combination of the two was found to be an independent factor predicting mortality with hazard ratio of 2.93, which was statistically significant [26]. There are occasional reports on the use of lopinavir/ritonavir $[26,34]$ in lung cancer patient with Covid. Another dataset from CCC19 study reported on 2186 patients treated with hydroxychloroquine ( $n=538,25 \%)$, azithromycin $(n=$ $485,22 \%)$, remdesivir $(n=124,6 \%)$, high-dose corticosteroids $(n=109,5 \%)$, tocilizumab $(n=94,4 \%)$, and other therapy $(n=90,4 \%)$ showed no benefit of any treatment. Apart from slight activity of remdesivir no 
other drug showed any benefit [26, 35]. Patients also received dexamethasone, aspirin, low-molecular weight heparin, and other anti-coagulants besides above treatments.

\section{Research on Covid-2019 and cancer}

A recent bioinformatic study using the GEO database showed that angiotensin-converting enzyme 2 (ACE2) is elevated in uterine corpus endometrial carcinoma and renal papillary cell carcinoma. This increase also correlated with immune infiltrate present in the tumor; the authors suggested that these tumors may be more prone to Covid-19 infections [36]; however, the authors failed to present any evidence to suggest this hypothesis. Similar bioinformatics study by $\mathrm{Fu}$ et al. also showed similar results and they suggested that testes may also get affected by Covid-19 infections [37]. Other tumors that may be affected are pancreas and colon [38]. However, all these studies are based on GEO databases and there is no experimental evidence presented till date.

\section{Conclusions}

The literature on cancer and Covid is fast expanding with more and more information pouring in. The literature so far is clear in indicating that cancer patients are at high risk of developing Covid and when developed, the severity and mortality is higher than the normal population. The recent data also suggests a possible role of remdesivir in the treatment of Covid-19 in cancer patients; however, the evidence to support this is very weak. This absence of conclusive evidences has led to development of strategies to treat cancer safely; most of these are based on reducing the hospital visits and avoiding immune compromise. The evidence is still evolving and more practice changes are expected in the days to come and that may continue even in post Covid era.

\section{Acknowledgements}

None

\section{Authors' contributions}

MC prepared the draft article and MP conceived and designed the article and edited the final version. The authors read and approved the final manuscript.

\section{Funding}

None

\section{Availability of data and materials}

Not applicable

\section{Ethics approval and consent to participate}

This article does not report on human and animal experiments; ethical approval and publication of consent is not applicable.

\section{Consent for publication}

Not applicable

\section{Competing interests}

The authors declare that there are no conflicts of interest.
Received: 7 June 2020 Accepted: 17 August 2020

Published online: 22 August 2020

\section{References}

1. Wise J. Covid-19: Cancer mortality could rise at least $20 \%$ because of pandemic, study finds. BMJ. 2020;369:m1735. https://doi.org/10.1136/bmj. m1735.:m1735

2. Civantos FJ, Leibowitz JM, Arnold DJ, Stubbs VC, Gross JH, Thomas GR, Sargi Z, Casiano RR, Franzmann EJ, Weed D, Perez C, Samuels M, Goodman KW, Goodwin WJ. Ethical surgical triage of head and neck cancer patients during the COVID-19 pandemic. Head Neck. 2020;10.

3. Coles CE, Aristei C, Bliss J, Boersma L, Brunt AM, Chatterjee S, Hanna G, Jagsi R, Kaidar PO, Kirby A, Mjaaland I, Meattini I, Luis AM, Marta GN, Offersen B, Poortmans $\mathrm{P}$, Rivera S. International guidelines on radiation therapy for breast cancer during the COVID-19 pandemic. Clin Oncol (R Coll Radiol). 2020;32:279-81.

4. Cortiula F, Pettke A, Bartoletti M, Puglisi F, Helleday T. Managing COVID-19 in the oncology clinic and avoiding the distraction effect. Ann Oncol. 2020; 31:553-5.

5. Elkaddoum R, Haddad FG, Eid R, Kourie HR. Telemedicine for cancer patients during COVID-19 pandemic: between threats and opportunities. Future Oncol. 2020:10-0324.

6. Finley C, Prashad A, Camuso N, Daly C, Aprikian A, Ball CG, Bentley J, Charest D, Fata P, Helyer L, O'Connell D, Moloo H, Seely A, Werier J, Zhong T, Earle CC. Guidance for management of cancer surgery during the COVID19 pandemic. Can J Surg. 2020;63:S2-4.

7. Finley C, Prashad A, Camuso N, Daly C, Earle CC. Lifesaving cancer surgeries need to be managed appropriately during the COVID-19 pandemic. Can J Surg. 2020;63:S1

8. Hanna TP, Evans GA, Booth CM. Cancer, COVID-19 and the precautionary principle: prioritizing treatment during a global pandemic. Nat Rev Clin Oncol. 2020;17:268-70.

9. Dai M, Liu D, Liu M, Zhou F, Li G, Chen Z, Zhang Z, You H, Wu M, Zheng Q, Xiong $Y$, Xiong $\mathrm{H}$, Wang $\mathrm{C}$, Chen $\mathrm{C}$, Xiong $\mathrm{F}$, Zhang $Y$, Peng $Y$, Ge $\mathrm{S}$, Zhen $\mathrm{B}$, Yu T, Wang L, Wang H, Liu Y, Chen Y, Mei J, Gao X, Li Z, Gan L, He C, Li Z, Shi Y, Qi Y, Yang J, Tenen DG, Chai L, Mucci LA, Santillana M, Cai H. Patients with cancer appear more vulnerable to SARS-COV-2: a multi-center study during the COVID-19 outbreak. Cancer Discov. 2020:2159-8290.

10. Deng G, Yin M, Chen X, Zeng F. Clinical determinants for fatality of 44,672 patients with COVID-19. Crit Care. 2020;24:179-02902.

11. Casanova M, Pagani BE, Silva M, Patriarca C, Veneroni L, Clerici CA, Spreafico F, Luksch R, Terenziani M, Meazza C, Podda M, Biassoni V, Schiavello E, Chiaravalli S, Puma N, Bergamaschi L, Gattuso G, Sironi G, Massimino M, Ferrari A: How young patients with cancer perceive the COVID-19 (coronavirus) epidemic in Milan, Italy: is there room for other fears? Pediatr Blood Cancer 2020:e28318.

12. Wu Y, Wang J, Luo C, Hu S, Lin X, Anderson AE, Bruera E, Yang X, Wei $S$, Qian Y. A comparison of burnout frequency among oncology physicians and nurses working on the front lines and usual wards during the COVID-19 epidemic in Wuhan, China. J Pain Symptom Manag. 2020;10.

13. Guan WJ, Ni ZY, Hu Y, Liang WH, Ou CQ, He JX, Liu L, Shan H, Lei CL, Hui DSC, Du B, Li LJ, Zeng G, Yuen KY, Chen RC, Tang CL, Wang T, Chen PY, Xiang J, Li SY, Wang JL, Liang ZJ, Peng YX, Wei L, Liu Y, Hu YH, Peng P, Wang JM, Liu JY, Chen Z, Li G, Zheng ZJ, Qiu SQ, Luo J, Ye CJ, Zhu SY, Zhong NS. Clinical characteristics of coronavirus disease 2019 in China. N Engl J Med. 2020;382:1708-20.

14. Cai YC, Wang W, Li C, Zeng DF, Zhou YQ, Sun RH, Jiang H, Guo H, Wang SX, Jiang J: Treating head and neck tumors during the SARS-CoV-2 epidemic, 2019 to 2020: Sichuan Cancer Hospital. Head Neck 2020:10.

15. Chen ATC, Coura-Filho GB, Rehder MHH: Clinical characteristics of Covid-19 in China. N Engl J Med 2020, 382. pii: 10.1056/NEJMc2005203\#sa2. doi: 10. 1056/NEJMc2005203.:10.

16. Fong $D$, Rauch $S$, Petter $C$, Haspinger $E$, Alber M, Mitterer M. Infection rate and clinical management of cancer patients during the COVID-19 pandemic: experience from a tertiary care hospital in northern Italy. ESMO Open. 2020;5:e000810.

17. Yu J, Ouyang W, Chua MLK, Xie C. SARS-CoV-2 transmission in patients with cancer at a tertiary care hospital in Wuhan, China. JAMA Oncol. 2020; 2763673. 
18. Desai A, Sachdeva S, Parekh T, Desai R. COVID-19 and cancer: lessons from a pooled meta-analysis. JCO Glob Oncol. 2020;6:557-9. https://doi.org/10. 1200/GO.20.00097:.557-559.

19. Lee LYW, Cazier JB, Starkey T, Turnbull CD, Kerr R, Middleton G: COVID-19 mortality in patients with cancer on chemotherapy or other anticancer treatments: a prospective cohort study. Lancet 2020, \%20;395:1919-1926.

20. Giannakoulis VG, Papoutsi $E$, Siempos II. Effect of cancer on clinical outcomes of patients with COVID-19: a meta-analysis of patient data. JCO Glob Oncol. 2020;6:799-808. https://doi.org/10.1200/GO.20.00225:799-808.

21. Gosain R, Abdou Y, Singh A, Rana N, Puzanov I, Ernstoff MS. COVID-19 and cancer: a comprehensive review. Curr Oncol Rep. 2020;22:53-00934.

22. Addeo A, Obeid M, Friedlaender A. COVID-19 and lung cancer: risks, mechanisms and treatment interactions. J Immunother Cancer. 2020;8: e000892.

23. Yang $K$, Sheng $Y$, Huang $C$, Jin $Y$, Xiong N, Jiang $K$, Lu H, Liu J, Yang J, Dong Y, Pan D, Shu C, Li J, Wei J, Huang Y, Peng L, Wu M, Zhang R, Wu B, Li Y, Cai L, Li G, Zhang T, Wu G. Clinical characteristics, outcomes, and risk factors for mortality in patients with cancer and COVID-19 in Hubei, China: a multicentre, retrospective, cohort study. Lancet Oncol. 2020;21:904-13.

24. Mehta V, Goel S, Kabarriti R, Cole D, Goldfinger M, Acuna-Villaorduna A, Pradhan K, Thota R, Reissman S, Sparano JA, Gartrell BA, Smith RV, Ohri N, Garg M, Racine AD, Kalnicki S, Perez-Soler R, Halmos B, Verma A. Case fatality rate of cancer patients with COVID-19 in a New York hospital system. Cancer Discov. 2020;10:935-41.

25. Meng Y, Lu W, Guo E, Liu J, Yang B, Wu P, Lin S, Peng T, Fu Y, Li F, Wang Z, Li Y, Xiao R, Liu C, Huang Y, Lu F, Wu X, You L, Ma D, Sun C, Wu P, Chen G. Cancer history is an independent risk factor for mortality in hospitalized COVID-19 patients: a propensity score-matched analysis. J Hematol Oncol. 2020;13:75-00907.

26. Kuderer NM, Choueiri TK, Shah DP, Shyr Y, Rubinstein SM, Rivera DR, Shete S, Hsu CY, Desai A, de Lima LG, Jr., Grivas P, Painter CA, Peters S, Thompson MA, Bakouny Z, Batist G, Bekaii-Saab T, Bilen MA, Bouganim N, Larroya MB, Castellano D, Del Prete SA, Doroshow DB, Egan PC, Elkrief A, Farmakiotis D, Flora D, Galsky MD, Glover MJ, Griffiths EA, Gulati AP, Gupta S, Hafez N, Halfdanarson TR, Hawley JE, Hsu E, Kasi A, Khaki AR, Lemmon CA, Lewis C, Logan B, Masters T, McKay RR, Mesa RA, Morgans AK, Mulcahy MF, Panagiotou OA, Peddi P, Pennell NA, Reynolds K, Rosen LR, Rosovsky R, Salazar M, Schmidt A, Shah SA, Shaya JA, Steinharter J, Stockerl-Goldstein KE, Subbiah S, Vinh DC, Wehbe FH, Weissmann LB, Wu JT, Wulff-Burchfield E, Xie Z, Yeh A, Yu PP, Zhou AY, Zubiri L, Mishra S, Lyman GH, Rini BI, Warner $J$ L: Clinical impact of COVID-19 on patients with cancer (CCC19): a cohort study. Lancet 2020, \%20;395:1907-1918.

27. Huang SH, O'Sullivan B, Su J, Ringash J, Bratman SV, Kim J, Hosni A, Bayley A, Cho J, Giuliani M, Hope A, Spreafico A, Hansen AR, Siu LL, Gilbert R, Irish JC, Goldstein D, de AJ, Tong L, Xu W, Waldron J. Hypofractionated radiotherapy alone with $2.4 \mathrm{~Gy}$ per fraction for head and neck cancer during the COVID-19 pandemic: the Princess Margaret experience and proposal. Cancer. 2020;126:3426-37.

28. Vordermark D. Shift in indications for radiotherapy during the COVID-19 pandemic? A review of organ-specific cancer management recommendations from multidisciplinary and surgical expert groups. Radiat Oncol. 2020;15:140-01579.

29. Davis AP, Boyer M, Lee JH, Kao SC. COVID-19: the use of immunotherapy in metastatic lung cancer. Immunotherapy. 2020:10-0096.

30. Kattan J, Kattan C, Assi T. Do checkpoint inhibitors compromise the cancer patients' immunity and increase the vulnerability to COVID-19 infection? Immunotherapy. 2020:10-0077.

31. Bersanelli M. Controversies about COVID-19 and anticancer treatment with immune checkpoint inhibitors. Immunotherapy. 2020;12:269-73.

32. Ardura Ml, Hartley DM, Dandoy C, Lehmann L, Jaglowski S, Auletta JJ. Addressing the impact of the coronavirus disease (COVID-19) pandemic on hematopoietic cell transplantation: Learning networks as means for sharing best practices. Biol Blood Marrow Transplant. 2020;10.

33. Mahmoudjafari Z, Alexander M, Roddy J, Shaw R, Shigle TL, Timlin C, Culos K. American Society for Transplantation and Cellular Therapy Pharmacy Special Interest Group position statement on pharmacy practice management and clinical management for COVID-19 in hematopoietic cell transplantation and cellular therapy patients in the United States. Biol Blood Marrow Transplant. 2020;10.
34. Zhang H, Xie C, Huang Y. Treatment and outcome of a patient eith lung cancer infected with severe acute respiratory syndrome coronavirus-2. J Thorac Oncol. 2020;15:e63-4.

35. Rivera DR, Peters S, Panagiotou OA, Shah DP, Kuderer NM, Hsu CY, Rubinstein SM, Lee BJ, Choueiri TK, de Lima LG, Grivas P, Painter CA, Rini BI, Thompson MA, Arcobello J, Bakouny Z, Doroshow DB, Egan PC, Farmakiotis D, Fecher LA, Friese CR, Galsky MD, Goel S, Gupta S, Halfdanarson TR, Halmos B, Hawley JE, Khaki AR, Lemmon CA, Mishra S, Olszewski AJ, Pennell NA, Puc MM, Revankar SG, Schapira L, Schmidt A, Schwartz GK, Shah SA, Wu JT, Xie Z, Yeh AC, Zhu H, Shyr Y, Lyman GH, Warner JL: Utilization of COVID-19 treatments and clinical outcomes among patients with cancer: a COVID-19 and Cancer Consortium (CCC19) cohort study. Cancer Discov 2020:CD-0941.

36. Yang J, Li H, Hu S, Zhou Y. ACE2 correlated with immune infiltration serves as a prognostic biomarker in endometrial carcinoma and renal papillary cell carcinoma: implication for COVID-19. Aging (Albany NY). 2020;12:6518-35.

37. Fu J, Zhou B, Zhang L, Balaji KS, Wei C, Liu X, Chen H, Peng J, Fu J. Expressions and significances of the angiotensin-converting enzyme 2 gene, the receptor of SARS-CoV-2 for COVID-19. Mol Biol Rep. 2020;47:4383-92.

38. Chai P, Yu J, Ge S, Jia R, Fan X. Genetic alteration, RNA expression, and DNA methylation profiling of coronavirus disease 2019 (COVID-19) receptor ACE2 in malignancies: a pan-cancer analysis. J Hematol Oncol. 2020;13:43-00883.

\section{Publisher's Note}

Springer Nature remains neutral with regard to jurisdictional claims in published maps and institutional affiliations.
Ready to submit your research? Choose BMC and benefit from:

- fast, convenient online submission

- thorough peer review by experienced researchers in your field

- rapid publication on acceptance

- support for research data, including large and complex data types

- gold Open Access which fosters wider collaboration and increased citations

- maximum visibility for your research: over $100 \mathrm{M}$ website views per year

At BMC, research is always in progress.

Learn more biomedcentral.com/submissions 